\title{
Phytochemical Profiling, Antibacterial Potential and GC-MS Analysis of Methanol Leaf Extract of Enicostemma axillare
}

\author{
K. Mullai Nila and J. Karthikeyan* \\ Department of Zoology, Presidency College (Autonomous), Chennai-600005, Tamil Nadu, India \\ *Corresponding author
}

\begin{tabular}{|c|c|}
\hline & A B S T R A C T \\
\hline $\begin{array}{l}\text { Ke y w or d s } \\
\text { Enicostemma } \\
\text { axillare, } \\
\text { antibacterial } \\
\text { activity, E. coli, } \\
\text { GC-MS, Phytol. }\end{array}$ & $\begin{array}{l}\text { Aim of the study is to identify and characterize the bioactive compounds from } \\
\text { methanol leaf extract of Enicostemma axillare responsible for the bactericidal } \\
\text { activity. The in vitro antibacterial activity was determined by disc diffusion } \\
\text { method against Escherichia coli, Klebsiella pneumoniae, Proteus mirabilis, } \\
\text { Enterococcus faecalis and Bacillus subtilis. Gas Chromatography-Mass } \\
\text { Spectrometry (GC-MS) studies were carried out to identify the presence of } \\
\text { bioactive compounds. Antibacterial studies reveal a dose-dependent zone of }\end{array}$ \\
\hline Article Info & \\
\hline $\begin{array}{l}\text { Accepted: } \\
\text { 29 June } 2017 \\
\text { Available Online: } \\
10 \text { July } 2017\end{array}$ & $\begin{array}{l}\text { Observation of GC-MS results shows the presence of antibacterial compounds } \\
\text { glycine, N- methyl ester, octadecatrienoic acid, 1-heptatriacetanol, and } \\
\text { tetramethyl-2-hexadecen-1-ol were identified. It is concluded that the methanolic } \\
\text { leaf extract from Enicostemma axillare possesses the potential compounds } \\
\text { responsible for the antibacterial activity. }\end{array}$ \\
\hline
\end{tabular}

\section{Introduction}

Enicostemma axillare is a perennial herb found throughout India and common in coastal areas. It is commonly known as Vellarugu in Tamil, Chotachirayata in Hindi, Mamejavo in Gujarati and Nagajivha in Bengal. The plant possesses antiinflammatory (Sadique et al., 1987), hypoglycemic (Murali et al., 2002) and anticancer (Jyoti et al., 2003), antimalarial, antipyretic (Varier, 2001) properties. Further crude extract from these plants was used in folk medicine to treat diabetes mellitus, rheumatism, abdominal ulcers, hernia, swelling, itching and insect poisoning (Kirtikar and Basu, 1999). It is also used traditionally for blood purifier and to treat snake bites (Garg, 2000-2001). Infectious diseases are the leading cause of death worldwide (Gannon, 2000). The reemergence of deadly infectious diseases, and the increasing prevalence of antimicrobial resistant strains presents a formidable threat to public health and welfare.

Recently, significant evidence has emerged which indicates that markedly different microbial pathogens use common strategies to cause infection and disease (Wilson et al., 2002). The indiscriminate use of various antibiotics increases their resistance to microorganisms, giving rise to multidrug resistant strains, which has become a global 
concern (Shariff, 2001). This paves the way for the search and identification of a new antibacterial compound. Isolation of antibacterial compounds from the medicinal plants seems to be a potential alternative to the control of multidrug resistant strains. The medicinal plants possess a wide variety of chemical substances which could be explored for pharmaceutical applications (Periyasami and Kaliyaperumal, 2016; Malakar and Choudhury, 2015). This study showed the presence of novel compounds with antibacterial activity in the methanol leaf extract from Enicostemma axillare.

\section{Materials and Methods}

\section{Collection and identification of Enicostemma axillare}

The whole plants of Enicostemma axillare (Fig. 1) were collected from Pudukkottai district of Tamil Nadu, India. The plants were authenticated by Captain Srinivasa Murthi, Multi Drug Research Center for Siddha and Ayurveda, Chennai, 600029 (Voucher specimen No: 00299).

The leaves were dried under shade, then ground into a uniform powder using a mechanical blender and stored in an airtight bottle at room temperature.

\section{Chemicals and reagents}

Methanol, Dimethyl sulfoxide (DMSO), Muller Hinton agar and other chemicals used for the phytochemical studies and disk diffusion methods were brought from Himedia Laboratory, Mumbai, India.

\section{Extract preparation}

Fifty grams of the shade dried and powdered material (leaves) were packed and extracted from methanol using a Soxhlet apparatus for
$12 \mathrm{~h}$ at $45^{\circ} \mathrm{C}$. The sample was concentrated using rotary evaporator and stored at $4{ }^{0} \mathrm{C}$ for further studies.

\section{Preliminary phytochemical analysis}

The crude plant extract was subjected to qualitative phytochemical tests to identify various classes of bioactive chemical constituents present in the leaves using standard procedures (Harborne, 1973; Edeoga and Gomina, 2000). Visible color change or precipitate formation was taken into consideration in the presence $(+)$ or absence $(-)$ of particular active constituents.

\section{Collection and maintenance of bacterial strains}

The pure cultures such as Escherichia coli, Klebsiella pneumoniae, Proteus mirabilis, Enterococcus faecalis and Bacillus subtilis were collected from King Institute of Preventive medicine, Guindy, Chennai. The organisms were sub-cultured and maintained in the laboratory

\section{In vitro antibacterial activity by disc diffusion method}

Antibacterial activities of the leaf extract were determined using a disc diffusion method (Kirby-Bauer, 1966). Freshly prepared Mueller-Hinton Agar plates were seeded with the bacterial inoculum $\left(10^{-5}\right)$ to obtain lawn culture. Sterile discs ( $\sim 6 \mathrm{~mm}$ diameter) impregnated with concentrations of methanol leaf extracts $(10,15,20,25 \mathrm{mg} / \mathrm{ml})$ were placed on the inoculated Mueller Hinton agar.

Amikacin $(30 \mu \mathrm{g} / \mathrm{disc})$ was used as standard antibiotics. The plates were then incubated at $37^{\circ} \mathrm{C}$ for $18 \mathrm{~h}$, the zone of inhibition determined by measuring the diameter of the inhibition zone $(\mathrm{mm})$ using a transparent scale. 
GC-MS spectral analysis of Enicostemma axillare methanolic leaf extract

The components of test sample were evaporated in the injection port of the GC equipment which consists of GC-MS (Jeol GC Mate). The GC column was equipped with a capillary column $(30 \mathrm{~mm} \times 0.25 \mathrm{~mm})$, composed of $100 \%$ Dimethyl poly siloxane). For Mass Spectra detection, an electron ionization system with a ionizing energy of 70 $\mathrm{eV}$ was used. Helium gas (99.999\%) was used as the carrier gas at a constant flow rate of 1.4 $\mathrm{ml} / \mathrm{min}$ and an injection volume of $2 \mu \mathrm{l}$ was employed (split ratio of 10:1) Injector temperature $250^{\circ} \mathrm{C}$, Ion source temperature $280^{\circ} \mathrm{C}$. The oven temperature was programmed from $110^{\circ} \mathrm{C}$ (isothermal for 2 min.), with an increase of $10^{\circ} \mathrm{C} / \mathrm{min}$ to $200^{\circ} \mathrm{C}$, then $5{ }^{\circ} \mathrm{C} / \mathrm{min}$ to $280^{\circ} \mathrm{C}$, ending with a $9 \mathrm{~min}$ isothermal at $280^{\circ} \mathrm{C}$. Mass spectrum was taken at $70 \mathrm{eV}$ a scan interval. The chromatogram and mass spectra were evaluated using the software embedded in the GC-MS system.

\section{Identification of phyto compounds}

Interpretation of the mass spectrum was conducted using the database of National Institute Standard and Technology (NIST) (NIST, 2010). The compound bioactivity prediction is based on Dr. Duke's Phytochemical and Ethnobotanical Databases (Duke, 2002). The relative percentage amount of each photo-component was calculated by comparing its average peak area to the total area.

\section{Results and Discussion}

Medicinal plants are the richest source of secondary metabolites with various biological activities. In the present study phytochemicals from the methanolic leaf extract of Enicostemma axillare revealed the presence of alkaloid, coumarin, flavonoid, tannin, phenols, cardiac glycoside, anthocyanin, carbohydrates, quinine and terpenoid. Among these, the strong presence of phytocompounds was alkaloid and flavonoid, quinones, coumarins were moderate presence and saponin, steroids, leucoanthocyanin were absent in this plant methanol leaf extract (Table 1). The presence of different phytoconstituents in the whole plant extract from Enicostemma axillare has been reported earlier by Leelaprakash and Mohan Das (2012). Leaves of medicinal palnts possess antibacterial activity can be supplemented against moderately sensitive antibiotics (Kamath et al., 2017).

Phenolic compounds present in the Enicostemma axillare may contribute to its antibacterial activity and thus the plant is used in herbal treatment. A phenol has been found to be used in the preparation of some antimicrobial and antioxidant compounds (Brewer, 2011). There was a close correlation between the antibacterial activity and the amount of polyphenols, flavonoids and flavonols found in the plant. Total phenolic and total flavonoid contents were directly related to the antioxidant and antibacterial potential of the plant extracts (Bagdassarian et al., 2013). Alkaloids are considered as the largest group of secondary plant metabolites having nitrogenous bases which also exhibit a range of pharmaceutical activity such as antimicrobial property (Hadi and Bremner, 2001).

The analysis of the results in table 2 shows that the crude extracts from the tested plant show maximum activity against $E$. coli and Klebsiella pneumoniae. The zone of inhibition observed with reference to drugresistant E. coli is higher than the standard antibiotic amikacin with the concentration of $30 \mu \mathrm{g} / \mathrm{ml}$. The antibacterial activity was more pronounced on gram-negative bacteria 
(Klebsiella pneumoniae and E. coli) than the gram positive bacteria (Bacillus subtilis).

The results of the present studies are in agreement with the above findings as the methanolic leaf extract shows a strong presence of alkaloids, flavonoids along with terpenoids, quinine, coumarins, tannin, cardiac glycosides, anthocyanin. These phytocompounds mainly targeting the cell wall of bacteria (Cowan, 1999) inactivates microbial enzymes, cell wall protein (Jones et al., 1994) and also cause loss of cellular function (Kazmi et al., 1994). Hence, the methanolic extract shows maximum antibacterial activity against $E$. coli $(8-10 \mathrm{~mm})$ at $10,15,20$ and $25 \mathrm{mg} / \mathrm{ml}$ concentration of plant extracts.

Table.1 Phytoconstituents of methanol leaf extract of Enicostemma axillare

\begin{tabular}{|l|l|}
\hline Phytoconstituents & Methanol Extract \\
\hline Alkaloids & +++ \\
\hline Flavonoids & ++ \\
\hline Tannin & + \\
\hline Cardiac glycosides & + \\
\hline Phenol & + \\
\hline Steroids & - \\
\hline Terpenoids & + \\
\hline Anthocyanin & + \\
\hline Leuco anthocyanin & - \\
\hline Quinone & ++ \\
\hline Saponin & - \\
\hline Protein & + \\
\hline Carbohydrate & + \\
\hline Phenol & + \\
\hline
\end{tabular}

Table.2 Major Components of the methanol leaf extract of Enicostemma axillare

\begin{tabular}{|c|c|c|c|c|c|}
\hline S.No & Name of the compounds & RT & $\begin{array}{l}\text { Area } \\
\%\end{array}$ & M.W & M.F \\
\hline 1 & Propanoic acid -2(3-acetoxy-4,4,14-trimethylandrost-8-en-17-yl) & 19.12 & 6.4 & 208.21 & $\mathrm{C}_{11} \mathrm{H}_{12} \mathrm{O}_{4}$ \\
\hline 2 & $\begin{array}{l}\text { Glycine,N-[(3a,5a,7a12a-Oxo-3,7,12-Tris [(trimethylsily) } \\
\text { cholan-24-y] methyl ester }\end{array}$ & 20.45 & 7.72 & 185.10 & $\begin{array}{l}\mathrm{C}_{5} \mathrm{H}_{6} \mathrm{~F}_{3} \mathrm{~N} \\
\mathrm{O}_{3}\end{array}$ \\
\hline 3 & $\begin{array}{l}\text { Acetamide,N-methyl-N-[4[4-fluoro-1-heahydropyridyl]2- } \\
\text { butynyl]- }\end{array}$ & 3.95 & 4.32 & 179.22 & $\mathrm{C}_{13} \mathrm{H}_{9} \mathrm{~N}$ \\
\hline 4 & Benzolic acid, 3-methyl-2-trimethylsilyloxy-trimethylsilyl ester & 11.25 & 6.7 & 135.18 & $\mathrm{C}_{7} \mathrm{H}_{5} \mathrm{NS}$ \\
\hline 5 & $\begin{array}{l}\text { 9,12,15-Octadecatrienoic acid, 2-trimethylsilyl0oxy] -1- } \\
\text { [(trimethylsilyl) Oxy] ethyl ester }\end{array}$ & 16.05 & 11.3 & 312.00 & $\mathrm{C}_{20} \mathrm{H}_{40} \mathrm{O}_{2}$ \\
\hline 6 & Cyclopropanebutanoic acid & 17.17 & 8.71 & 268.00 & $\mathrm{C}_{17} \mathrm{H}_{32} \mathrm{O}_{2}$ \\
\hline 7 & 1-Heptatriacotanol & 20.17 & 7.5 & 536.00 & $\mathrm{C}_{37} \mathrm{H}_{76} \mathrm{O}$ \\
\hline 8 & 3,7,11,15-Tetramethyl-2- hexadecen-1-ol (Phytol) & 10.75 & 9.85 & 296.00 & $\mathrm{C}_{20} \mathrm{H}_{40} \mathrm{O}$ \\
\hline
\end{tabular}


Table.3 Antibacterial efficacy of Enicostemma axillare methanol leaf extract against different Microorganisms

\begin{tabular}{|l|l|l|l|l|l|}
\hline \multirow{2}{*}{ Microorganisms } & \multicolumn{4}{|c|}{ Diameters of zones of Inhibition (in mm) } & Amikacin \\
\cline { 2 - 6 } & $10 \mu \mathrm{g}(\mathrm{A})$ & $15 \mu \mathrm{g}(\mathrm{B})$ & $20 \mu \mathrm{g}(\mathrm{C})$ & $25 \mu \mathrm{g}(\mathrm{D})$ & $30 \mu \mathrm{g} / \mathrm{ml}(\mathrm{E})$ \\
\hline Escherichia coli & 8 & 9 & 9 & 10 & 8 \\
\hline Enterococcus faecalis & 7 & 8 & 9 & 9 & 14 \\
\hline Klebsiella pneumonia & 7 & 8 & 9 & 12 & 15 \\
\hline Proteus mirabilis & 6 & 7 & 8 & 9 & 15 \\
\hline Bacillus subtilis & 7 & 7 & 7 & 8 & 15 \\
\hline
\end{tabular}

Fig.1 Enicostemma axillare

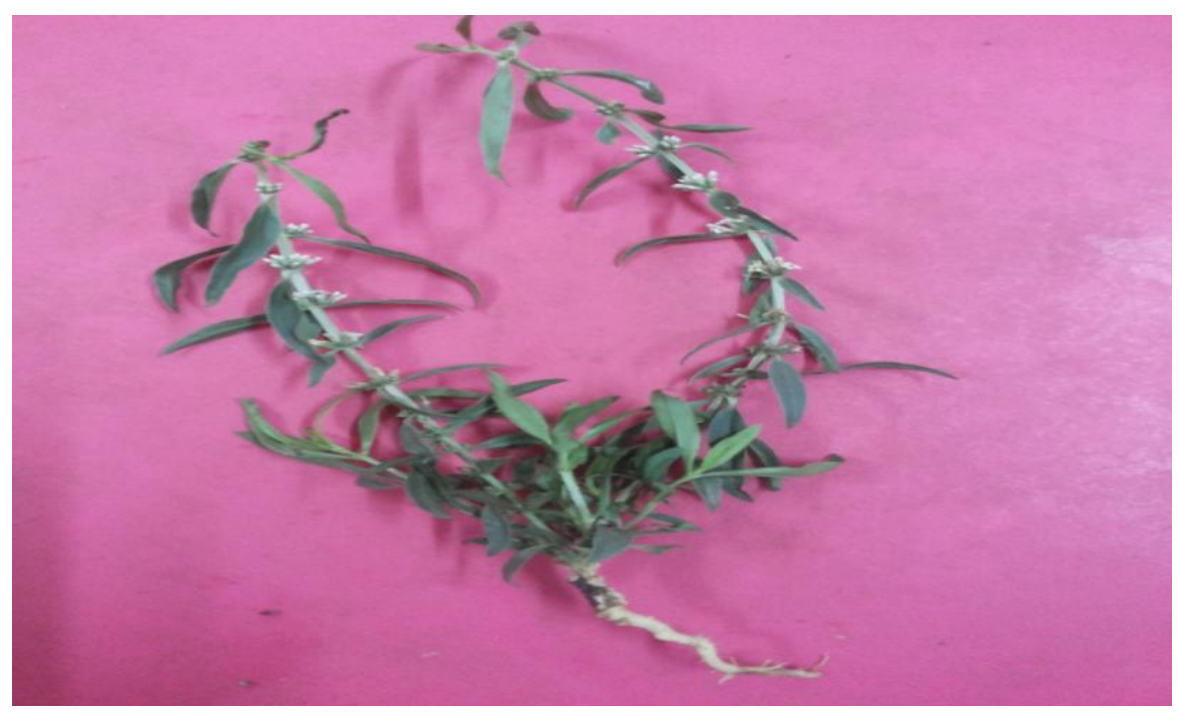

Fig.2 GC-MS spectral analysis of Enicostemma axillare methanolic leaf extract

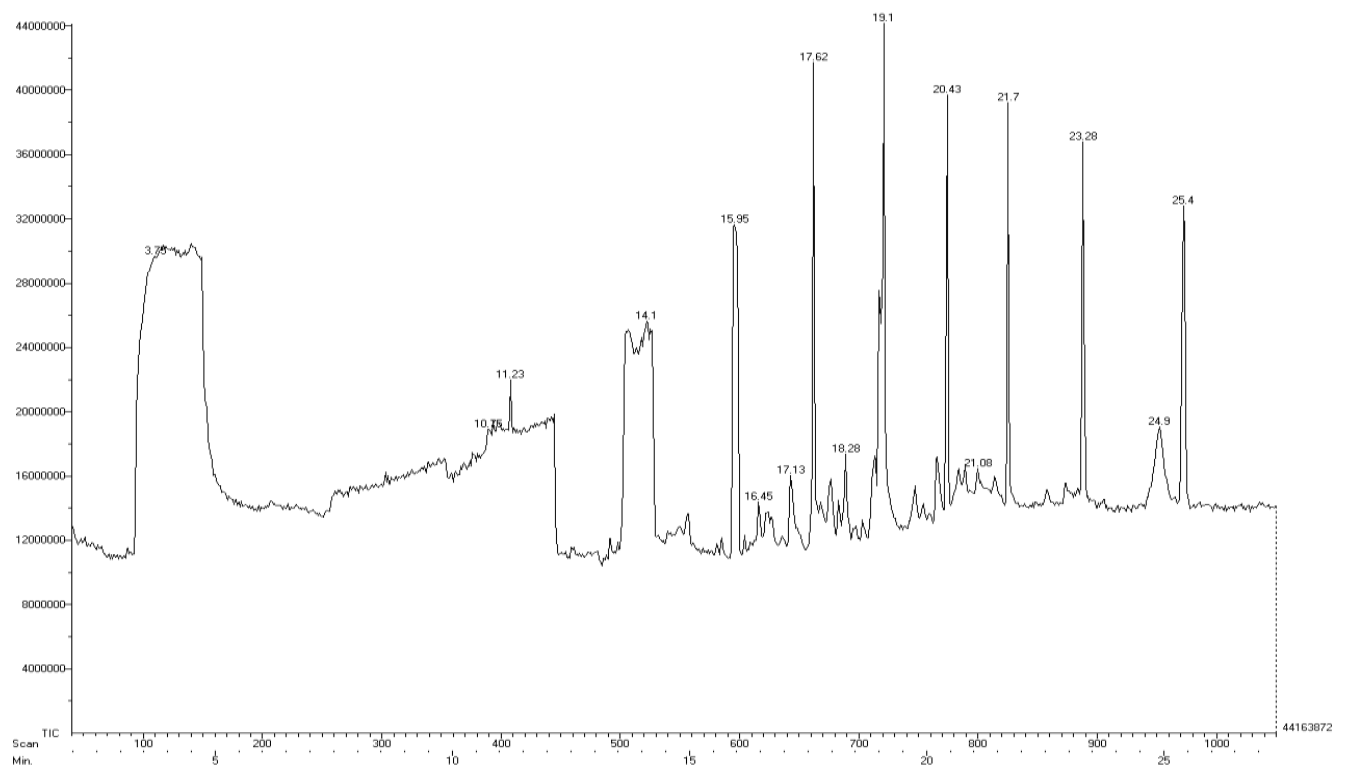


The result pertaining to GC-MS analysis leads to the identification of the number of compounds from the GC fractions of the methanolic leaf extract from Enicostemma axillare and these compounds were identified with mass spectrometry attached to GC. The results presented in table 3 and figure 2 reveals the presence of the major components Propanoic acid -2(3acetoxy4, 4, 14 trimethylandrost8en17yl,), Glycine, $\mathrm{N}[(3 \mathrm{a}, 5 \mathrm{a}, 7$ a12 aoxo3,7,12tris[(trimethylsily)cholan-24y] methylester, Acetamide,N-methy $1 \mathrm{~N}[4$ [4 fluoro1heahydropyridyl]2-butynyl]-,

Benzolicacid, 3-methyl-2-trimethylsilyloxytrimethylsilylester, 9,12,15-Octa decatrienoic acid, 2-trimethylsilyloxy]-1-[(trimethylsilyl) oxy] ethyl ester, Cyclopropane butanoic acid,1-Heptatriacotanol and 3,7,11,15Tetramethyl-2- hexadecen-1-ol of which many of the identified compounds seems to possess many biological activities.

GC-MS analysis of methanolic leaf extracts shows the presence of 8 compounds, of which Glycine, N, (3a,5a,7a,12a)24oxo3,7,12tris ((trimethylsily)) cholan-24yl) methyl ester, 9,12,15- Octadecatrienoicacid, 2 trimethylsilyl0oxy] -1-[(trimethylsilyl) Oxy] ethyl ester, 1-Heptatriacotanol and 3,7,11,15tetramethylhexadec-2-en-1-ol were responsible for the antibacterial activity. The previous studies are in support of the above findings (Adeneye and Agbaje, 2008; Senthilkumar and Kamaraj, 2010; Kumaradevan et al., 2015; Anand and Gokulakrishnan, 2012). In addition, compounds with anti-diabetic (Propanoic acid -2 (3-acetoxy-4, 4, 14-trimethylandrost-8-en17-yl) and anti-cancer activity (Benzolic acid, 3-methyl-2-trimethylsilyloxy-trimethylsilyl ester) were also observed.

It is evident from the results that the presence of a major antimicrobial compound phytol was responsible for the antibacterial activity. The phytol is the compound which inactivates the protein and enzymes present in the microorganisms. In addition, the compound has no remarkable toxicity and possess high stability (Alqasoumi et al., 2012; Khasawneh et al., 2011; Dagla et al., 2012). Thus, it is evident from the present findings that phytol along with other phytoconstituents plays a major role in the inhibition of the growth of drug resistant $E$. coli.

In conclusion biologically active molecules phytol from the leaves of Enicostemma axillare, acts against the multi-drug resistant bacterial strains such as E. coli and Klebsiella pneumoniae. Isolation and purification of the compounds will paves the way for the identification of novel compound with potential microbial activity.

\section{References}

Adeneye, AA andAgbaje, EO. 2008. Pharmacological evaluation of oral hypoglycemic and antidiabetic effects of fresh leaves ethanol extract of Morindalucida Benth in normal and alloxan -induced diabetic rats. Afr $J$ Biomed Res., 11:65-71.

Alqasoumi, SI., Soliman, G., Awaad, AS and Donia, A. 2012. Anti-inflammatory activity, safety and protective effects of Leptadeniapyrotechnica, Haloxylonsalicornicum and Ochradenusbaccatus in ulcerative colitis. Phytopharmacology, 2: 58-71.

Anand, T and Gokulakrishnan, K. 2012. Phytochemical Analysis of Hybanthus enneaspermus using UV, FTIR and GCMS. IOSR-PHR., 2:520-524.

Bagdassarian, VLC, Bagdassarian, K.S., and Atanassova, M.S 2013. Phenolic profile, antioxidant and antimicrobial activities from the Apiaceae family (Dry Seeds). Mintage J Pharmaceutical \& Medical Sci., 2(4): 26-31. 
Brewer, MS.2011. Natural Antioxidants: Sources, Compounds, Mechanisms of Action, and Potential Applications. Comprehensive Reviews in Food Science and Food Safety. 10: 221-245.

Cowan, MM. 1999. Plant products as antimicrobial agents. Clinical Microbiology Reviews, 12: 564-582.

Dagla, HR., Paliwal, A., Rathore, MS and Shekhawat, NS.2012.Micropropagation of Leptadenia pyrotechnica (Forsk.) decne: a multipurpose plant of an arid environment. J. of Sustainable Forestry, 31: 283-293.

Duke, J.A (2002) American Agricultural Research Service - Phytochemical and Ethanobotanical database. http://www.ars.grin.gov.duke/index.htm 1

Edeoga, HO and Gomina, A.2000. Nutritional values of some non-conventional leafy vegetables of Nigeria.J. Econ. Taxon. Bot., 24: 7- 13.

GannonJohn C.2000. The Global Infectious Disease Threat and Its Implications for the United States.,NIE 99-17D.

Garg, SC. 2000-2001. Ethno medicine for snakebite. J. Med Arom Plant Sci., 22(4A) and 23 (1A): 546-553.

Hadi, S and Bremner J, B.2001.Initial studies on alkaloids from Lombok medicinal plants. Molecules, 6: 117-129.

Harborne, JB.1973. Phytochemical methods. Chapman and Hall, Ltd. London. pp. 49-188.

Jones, GA., McAllister, TA, Muir, AD and Cheng, KJ.1994. Effects of Sainfoin (Onobrychis viciifolia scop.) condensed tannins on growth and proteolysis by four strains of Ruminal bacteria. Appl Environ Microbiol, 60:1374-1375.

Jyoti, M., Vasu, VT and Guptam, S.2003. Dose dependant hypoglycemic effect of aqueous extract of Enicostemma littoraleblum in allaxon- induced diabetic rats, Phytomedicine, 10: 196-
199.

Kamath, N., RitaSwaminathan and Neetin Desai. 2017. Phytochemical analysis and antibacterial activity of Annona muricata (LaxmanPhal) against ESBLs producers (Escherichia coli and Klebsiella pneumoniae). Int.J.Curr.Microbiol.App.Sci, $\quad$ 6(3): 1339-1344.

Kazmi,MH., Malik, A., Hameed, S., Akhtar, $\mathrm{N}$ and Ali, SN.1994. An anthraquinone derivative from Cassiaitalica. Phytochemistry, 36: 761-763.

Khasawneh,MA., Elwy, HM., Hamza, AA., Fawzi, NM and Hassan, AH.2011. Antioxidant, anti-lipoxygenase and cytotoxic activity of Leptadenia pyrotechnica (Forssk.) decne polyphenolic constituents. Molecules, 16: 7510-7521.

Kirby, WMM, Bauer, AW, Sherris, JC and Turck, M. $1966 . \quad$ Antibiotic susceptibility testing by a standardized single disc method. Am. J. Clin. Pathol, 36: 493-496.

Kirtikar, KR andBasu, BD.1999. Indian Medicinal Plants, second ed, Mahendra Pal Sing publication, Dehradun, pp. 1655-1656.

Kumaradevan, G., Damodaran, R., Mani, P., Dineshkumar, $\mathrm{G}$ and Jayaseelan, T.2015. Phytochemical screening and GC-MS analysis of bioactive components of ethanol leaves extract of Clerodendrum Phlomidis.(Linn) Am J Biol and Pharma Res., 2:142-148.

Leelaprakash and Mohan Das.2012. Antimicrobial activity and phytochemical screening of methanol extract of Enicostemma axillare. Int $J$ Pharm Pharm Sci., 4(1): 342-348.

Malakar, C and Choudhury, PPN.2015. Pharmacological Potentiality and medicinal uses of Ipomoea Aquatica Forsk: A Review. Asian J Pharm Clin Res., 8:60-63. 
Murali, B., Upadhyaya, UM and Goyal, RK.2002. Effect of chronic treatment with Enicostema littorale Blume in noninsulin dependent diabetic rats, $J$. Ethnopharmacol. 81:199-204.

NIST.2010. Automated mass spectral library with a search program (Data version: NIST11, version 2.0). National Institute of Standards and technology, Gaithersburg, MD., USA.

Periyasami, $\mathrm{K}$ and Kaliyaperumal, $\mathrm{S}$. 2016.Ethanobotanical, phytochemical and pharmaceutical studies of medicinal plant Ventilago madaraspatana gaertin (Red Creeper): A review. Int J Cur Phar Res. 8:16-18.

Sadique, J.,Chandra, T., Thenmozhi, V and Elango, V.1987.The anti-inflammatory activity Enicostemma littorale and
Mollugo cerviana, Biochem MED Metab Biol., 37: 167-176.

Senthilkumar, S andKamaraj, M.2010.Analysis of phytochemical constitution and antimicrobial activities of Cucumisanguria.L. against clinical pathogens. Am.Euras. J. Agri. Sci., 7: 176- 178.

Shariff, ZM. 2001. Modern Herbal Therapy for Common Ailments. Spectrum Books Ltd, Ibandan, Nigeria, Vol.1: pp. 9-84.

Varier, A.2001.Dictionary of Indian Raw Materials and Industrial Products. Indian Medicinal Plants, 5: 387.

Wilson, JW., Schurr, MJ., LeBlanc, CL., Ramamurthy, R., Buchanan, KL and Nickerson, CA.2002.Mechanisms of bacterial pathogenicity. Postgrad Med J., 78:216-224.

\section{How to cite this article:}

Mullai Nila, K. and Karthikeyan, J. 2017. Phytochemical Profiling, Antibacterial Potential and GC-MS Analysis of Methanol Leaf Extract of Enicostemma axillare. Int.J.Curr.Microbiol.App.Sci. 6(7): 2688-2695. doi: https://doi.org/10.20546/ijcmas.2017.607.378 